\title{
Coral Productivity Is Co-Limited by Bicarbonate and Ammonium Availability
}

\author{
Stephane Roberty *,+(D), Eric Béraud, Renaud Grover and Christine Ferrier-Pagès *(D) \\ Centre Scientifique de Monaco, 98000 Monaco, Monaco; eberaud@centrescientifique.mc (E.B.); \\ rgrover@centrescientifique.mc (R.G.) \\ * Correspondence: sroberty@uliege.be (S.R.); ferrier@centrescientifique.mc (C.F.-P.) \\ † Current address: InBioS-Animal Physiology, University of Liège, 4000 Liège, Belgium.
}

Received: 8 April 2020; Accepted: 24 April 2020; Published: 28 April 2020

check for updates

\begin{abstract}
The nitrogen environment and nitrogen status of reef-building coral endosymbionts is one of the important factors determining the optimal assimilation of phototrophic carbon and hence the growth of the holobiont. However, the impact of inorganic nutrient availability on the photosynthesis and physiological state of the coral holobiont is partly understood. This study aimed to determine if photosynthesis of the endosymbionts associated with the coral Stylophora pistillata and the overall growth of the holobiont were limited by the availability of dissolved inorganic carbon and nitrogen in seawater. For this purpose, colonies were incubated in absence or presence of $4 \mu \mathrm{M}$ ammonium and/or $6 \mathrm{mM}$ bicarbonate. Photosynthetic performances, pigments content, endosymbionts density and growth rate of the coral colonies were monitored for 3 weeks. Positive effects were observed on coral physiology with the supplementation of one or the other nutrient, but the most important changes were observed when both nutrients were provided. The increased availability of DIC and $\mathrm{NH}_{4}{ }^{+}$significantly improved the photosynthetic efficiency and capacity of endosymbionts, in turn enhancing the host calcification rate. Overall, these results suggest that in hospite symbionts are co-limited by nitrogen and carbon availability for an optimal photosynthesis.
\end{abstract}

Keywords: carbon limitation; nitrogen limitation; photosynthesis; calcification; Symbiodiniaceae

\section{Introduction}

Symbiotic associations between animals and photosynthetic microorganisms have resulted in some of the best physiological adaptations that have evolved in the animal kingdom [1]. Such associations have indeed increased fitness and aptitude for food acquisition, related to the photosynthetic capacity of the autotrophic symbionts and the capture of external prey by the host. The symbiosis established between reef-building corals (Cnidaria; Anthozoa; Scleractinia) and dinoflagellates of the Symbiodiniaceae family [2,3], is one of the most well-known marine nutritional symbioses, because corals are the cornerstone of reef ecosystems, providing, through their calcification process, a tridimensional structural framework that support a high biodiversity and productivity [4]. Their ecological success in nutrient-poor tropical waters is due to the sharing and the tight recycling of nutrients between the partners $[5,6]$. Symbionts, through photosynthesis, transform dissolved inorganic carbon (DIC) and nitrogen (DIN), as well as other nutrients, into organic molecules which are translocated to the host for most of its metabolic needs, such as respiration, calcification and energetic reserves [7-9]. In turn, the animal provides its symbionts with nutrients coming from the environment and from its metabolic waste products [10-12].

An efficient acquisition of DIC by the symbionts is a key process for the health of the symbiotic association, because the amount of DIC fixed and assimilated by the symbionts will also determine the amount of photosynthates transferred to the host for its own needs [9]. Both partners have 
developed multiple ways of acquiring and concentrating carbon for photosynthesis. In addition to $\mathrm{CO}_{2}$ derived from respiration, the animal delivers DIC from the water column (mainly $\mathrm{HCO}_{3}{ }^{-}$) to the symbionts through a combination of external and intracellular carbonic anhydrases [13-15], specific transporters [16] and $\mathrm{H}^{+}$-ATPase [17]. Then the $\mathrm{CO}_{2}$ concentrating mechanism (CCM) of the algae takes over to maximize carbon fixation $[18,19]$. Even though oceanic concentrations of DIC are high, DIC can be a source of limitation for the primary production of the symbionts $[15,20,21]$ although not in all coral species or environmental conditions $[15,22]$. This is due to the fact that the adequacy of the supply of DIC to the symbionts (with respect to saturation of demand) depends on diverse environmental factors, but also on symbiont density or holobiont metabolic needs, and is not yet well understood. Since symbiotic carbon acquisition is a key process for coral health, conditions which lead to increased photosynthetic efficiency of the symbionts under varying environmental conditions are therefore of interest for reef biologists, especially in this era of global changes.

The nitrogen environment and nitrogen status of the coral symbionts is one of the important factors determining optimal photosynthetic carbon acquisition and hence holobiont growth. In plants and free-living algae, carbon fixation and nitrogen assimilation are interdependent, because fixed carbon need to be coupled to a nitrogen source for amino acid production [23-27]. For instance, it was shown that $\mathrm{CO}_{2}$ deprivation inhibits $\mathrm{NH}_{4}{ }^{+}$uptake in the unicellular alga Cyanidium caldarium [24], but also that internal nitrogen levels modulate the photosynthetic response of the organisms to DIC enrichment [28]. In the coral-dinoflagellate association, the carbon-nitrogen coupling has been less studied than in plants and algae and has led to opposite conclusions, also depending on the nitrogen source (ammonium versus nitrate) and the nitrogen to phosphorus $(\mathrm{N}: \mathrm{P})$ ratios considered $[29,30]$. Overall, the above studies showed negative impacts of increased N:P ratios and nitrate enrichment on coral photosynthesis and health and a positive effect of ammonium enrichment. Nevertheless, for the same nitrogen source such as ammonium, controversies still exist. On the one hand, overall carbon acquisition (per holobiont surface area) or per symbiont cell was enhanced by heterotrophic feeding (ammonium source) or direct ammonium supplementation, suggesting that nitrogen, not carbon, was limiting symbiont photosynthesis [31-33]. On the other hand, when nitrogen enrichment of the seawater increased symbiont density [34-37], symbionts may compete for $\mathrm{CO}_{2}$ acquisition, and present decreased rates of photosynthesis per symbiont cell $[34,36]$. Such discrepancy in the effect of nitrogen enrichment on carbon acquisition can be due to differences in DIC limitation of the symbionts but remains to be investigated.

All together, these results suggest that the role of inorganic nutrient availability on the photosynthetic capacities of the coral holobiont is partly understood. The aim of this study was to test the DIC and ammonium $\left(\mathrm{NH}_{4}{ }^{+}\right)$limitation for the photosynthesis of the symbionts associated to the scleractinian coral Stylophora pistillata. We first assessed whether symbionts of S. pistillata, were DIC or $\mathrm{NH}_{4}{ }^{+}$limited under our oligotrophic culture conditions, by enriching seawater with either $4 \mu \mathrm{M}$ ammonium or $6 \mathrm{mM}$ bicarbonate. We also tested DIC limitation under nitrogen-enriched conditions. Such conditions will occur more and more frequently in eutrophic coastal reef waters, following urban and agricultural development $[30,38,39]$. In the present context of global change and anthropogenic impacts on coastal waters, experimental studies like this one will help develop adaptive management strategies for the future of coral reefs.

\section{Materials and Methods}

\subsection{Biological Material and Experimental Settings}

The effects of ammonium and bicarbonate enrichment were assessed in colonies of the scleractinian coral S. pistillata originating from the Gulf of Aqaba (Red Sea, Jordan). These colonies host Symbiodiniaceae of the genus Symbiodinium (ITS2 type: A1) and were grown at $25^{\circ} \mathrm{C}$, under a 12:12h light/dark cycle with $400 \mathrm{~W}$ metal halide lamps, providing about $200 \mu \mathrm{mol}$ photon $\mathrm{m}^{-2} \cdot \mathrm{s}^{-1}$ at the level of the colonies (measured with a spherical quantum sensor (LI-193) connected to a LI-COR data 
logger (LI-1000, LI-COR Biosciences, Lincoln, NE, USA). Seawater in the aquaria was continuously renewed by natural oligotrophic seawater and colonies were fed twice a week with freshly hatched Artemia salina nauplii. A total of 264 coral nubbins of similar size were cut from 6 parent colonies (22 per parent colony), suspended by nylon fishing lines and were evenly and equally distributed in eight aquaria of $25 \mathrm{~L}$. Nubbins were let to recover for 5 weeks, under the same conditions as the parent colonies except for light intensity that was increased to $250-300 \mu \mathrm{mol}$ photon $\mathrm{m}^{-2} \mathrm{~s}^{-1}$. Feeding was stopped 2 weeks prior to the beginning of the experimental treatments to avoid any interaction with the addition of inorganic nitrogen. After this period, each experimental treatment ran for 21 days and coral nubbins were sampled at days 1, 3, 7, 11 and 21. The 4 experimental treatments were tested in duplicated aquaria and consisted of: ambient ammonium $(<0.3 \mu \mathrm{M})$ and bicarbonate ( $2 \mathrm{mM}$ ) concentrations (control condition); $4 \mu \mathrm{M}$ ammonium and ambient bicarbonate concentration (' $+\mathrm{iN}$ ' condition); ambient ammonium concentration and $6 \mathrm{mM}$ bicarbonate (' $+\mathrm{iC}^{\prime}$ condition); $4 \mu \mathrm{M}$ ammonium and $6 \mathrm{mM}$ bicarbonate (' $+\mathrm{iC}$ and $\mathrm{iN}^{\prime}$ condition) (see Table 1). Stock solutions of seawater enriched with $5 \mathrm{mM}$ ammonium and/or $66.7 \mathrm{mM}$ bicarbonate were prepared in $100 \mathrm{~L}$ tanks (pH adjusted to 8.2) and injected into the respective experimental aquaria with a peristaltic pump, at a constant flow rate of $3.75 \mathrm{~mL} \mathrm{~min}^{-1}$. The ammonium concentration chosen is high but reflects the concentrations that may occur in some eutrophicated coral reefs [39]. Conversely, even if the predicted increase in atmospheric $\mathrm{CO}_{2}$ and consequent acidification of the oceans will increase the abundance of $\mathrm{HCO}_{3}{ }^{-}$ions and dissolved $\mathrm{CO}_{2}$ at the expense of $\mathrm{CO}_{3}{ }^{2-}$ [40], the $\mathrm{HCO}_{3}{ }^{-}$concentrations to which coral colonies were exposed in this study are higher, but comparable to previous studies which have investigated the limitation of symbionts in iC [20,41].

Table 1. Mean carbonate chemistry parameters and $\mathrm{NH}_{4}{ }^{+}$concentrations for the four treatments representing two $\mathrm{HCO}_{3}{ }^{-}$(control vs. $6000 \mu \mathrm{mol} \mathrm{kg}{ }^{-1}$ ) concentrations and two $\mathrm{NH}_{4}{ }^{+}$concentrations (control vs. $4 \mu \mathrm{M}) ; n=30$.

\begin{tabular}{|c|c|c|c|c|c|c|c|c|c|c|}
\hline & $\begin{array}{c}\text { Temp } \\
\left({ }^{\circ} \mathrm{C}\right)\end{array}$ & $\begin{array}{c}\text { pH } \\
\text { (NDS } \\
\text { scale) }\end{array}$ & $\begin{array}{c}\text { TA } \\
(\mu \mathrm{mol} \\
\left.\mathrm{kg}^{-1}\right)\end{array}$ & $\underset{\text { ( } \mathrm{pCO}_{2}}{\left.\mathrm{CO}_{2}\right)}$ & $\begin{array}{c}{\left[\mathrm{CO}_{2}\right]} \\
(\mu \mathrm{mol} \\
\left.\mathrm{kg}^{-1}\right)\end{array}$ & $\begin{array}{c}\mathrm{HCO}_{3}{ }^{-} \\
(\mu \mathrm{mol} \\
\left.\mathrm{kg}^{-1}\right)\end{array}$ & $\begin{array}{c}{\left[\mathrm{CO}_{3}{ }^{2-}\right]} \\
(\mu \mathrm{mol} \\
\left.\mathrm{kg}^{-1}\right)\end{array}$ & $\begin{array}{c}\Omega \\
\text { aragonite }\end{array}$ & $\begin{array}{l}\mathrm{xCO}_{2} \\
\text { (ppm) }\end{array}$ & $\begin{array}{c}{\left[\mathrm{NH}_{4}{ }^{+}\right]} \\
(\mu \mathrm{M})\end{array}$ \\
\hline Control & $\begin{array}{c}25.03 \pm \\
0.04\end{array}$ & $\begin{array}{c}8.04 \pm \\
0.02\end{array}$ & $\begin{array}{r}2447.82 \\
\pm 56.69\end{array}$ & $\begin{array}{c}609.52 \\
\pm 29.84\end{array}$ & $\begin{array}{c}16.97 \pm \\
0.84\end{array}$ & $\begin{array}{l}1988.18 \\
\pm 34.11\end{array}$ & $\begin{array}{c}186.24 \\
\pm 12.09\end{array}$ & $\begin{array}{c}2.89 \pm \\
0.19\end{array}$ & $\begin{array}{c}628.80 \\
\pm 30.76\end{array}$ & $\begin{array}{c}0.37 \pm \\
0.24\end{array}$ \\
\hline$+\mathrm{iC}$ & $\begin{array}{c}25.21 \pm \\
0.03\end{array}$ & $\begin{array}{c}8.07 \pm \\
0.05\end{array}$ & $\begin{array}{c}6959.37 \\
\pm \\
745.45\end{array}$ & $\begin{array}{c}1646.94 \\
\pm \\
210.85\end{array}$ & $\begin{array}{c}45.64 \pm \\
5.81\end{array}$ & $\begin{array}{c}5710.35 \\
\pm \\
557.25\end{array}$ & $\begin{array}{c}578.23 \\
\pm \\
109.01\end{array}$ & $\begin{array}{c}8.98 \pm \\
1.69\end{array}$ & $\begin{array}{c}1699.63 \\
\pm \\
217.67\end{array}$ & $\begin{array}{c}0.40 \pm \\
0.34\end{array}$ \\
\hline$+\mathrm{iN}$ & $\begin{array}{c}25.04 \pm \\
0.04\end{array}$ & $\begin{array}{c}8.16 \pm \\
0.03\end{array}$ & $\begin{array}{l}2310.56 \\
\pm 37.54\end{array}$ & $\begin{array}{c}407.70 \\
\pm 30.98\end{array}$ & $\begin{array}{c}11.35 \pm \\
0.87\end{array}$ & $\begin{array}{l}1762.06 \\
\pm 34.54\end{array}$ & $\begin{array}{c}219.27 \\
\pm 12.39\end{array}$ & $\begin{array}{c}3.40 \pm \\
0.19\end{array}$ & $\begin{array}{c}420.61 \\
\pm 31.94\end{array}$ & $\begin{array}{c}4.36 \pm \\
1.23\end{array}$ \\
\hline$+\mathrm{iC} \& \mathrm{iN}$ & $\begin{array}{c}25.06 \pm \\
0.09\end{array}$ & $\begin{array}{c}8.07 \pm \\
0.05\end{array}$ & $\begin{array}{c}6931.74 \\
\pm \\
712.58\end{array}$ & $\begin{array}{c}1625.05 \\
\pm \\
129.18\end{array}$ & $\begin{array}{c}45.21 \pm \\
3.54\end{array}$ & $\begin{array}{c}5682.74 \\
\pm \\
475.26\end{array}$ & $\begin{array}{c}578.16 \\
\pm \\
122.35\end{array}$ & $\begin{array}{c}8.97 \pm \\
1.90\end{array}$ & $\begin{array}{c}1676.55 \\
\pm \\
133.43\end{array}$ & $\begin{array}{c}4.46 \pm \\
1.09\end{array}$ \\
\hline
\end{tabular}

\subsection{Water Chemistry}

During the experiment, ammonium concentration, total alkalinity, and $\mathrm{pH}$ (NBS scale) in each treatment were monitored on a regular basis. Ammonium concentration was determined with a Proxima autoanalyzer (Alliance Instrument, Frépillon, France), according to the method of Holmes, et al. [42]. Total alkalinity was measured using a 888 Titrando titrator (Metrohm, Herisau, Switzerland). Seawater carbonate chemistry measurements (Table 1 ) was calculated using the program CO2SYS developed by [43], with the following constants: $\mathrm{K} 1, \mathrm{~K} 2$ from [44]; $\mathrm{KSO}_{4}$ source from [45]; and total boron source from [46].

\subsection{Symbiodiniaceae Density and Chlorophylls Content}

In order to determine Symbiodinium density, coral tissue was separated from the exoskeleton with compressed air in a known volume of filtered seawater (FSW). The slurry produced was homogenized using a Potter tissue grinder and the final volume of the homogenate was recorded. Three $125 \mu \mathrm{L}$ 
sub-samples was taken to measure symbiont cell concentration using a Z1 Beckman Coulter Particle Counter (Beckman, Brea, CA, USA). Chlorophylls $a$ and $c_{2}$ were extracted from $2 \mathrm{~mL}$ tissue homogenate in $2 \mathrm{~mL} 100 \%$ methanol at $4{ }^{\circ} \mathrm{C}$. After debris removal (centrifugation at $16,000 \times g$ for $20 \mathrm{~min}$ at $4{ }^{\circ} \mathrm{C}$ ), chlorophyll $a$ and $c_{2}$ concentrations were determined by spectrophotometry according to the equations of [47] for dinophytes. Data were then normalized to the surface area of the coral nubbins, measured using the wax dipping method described in [48].

\subsection{Pigment Content Analysis}

Six coral nubbins were sampled in each experimental condition, after 1, 3, 7, 11 and 21 days. Samples were placed for $15 \mathrm{~min}$ under $400 \mu \mathrm{mol}$ photons $\mathrm{m}^{-2} \mathrm{~s}^{-1}$ before being flash frozen in liquid nitrogen. They were then lyophilized, and pigments were extracted in $1.5 \mathrm{~mL}$ of MeOH (HPLC Grade, Merck, Darmstadt, Germany). Samples were then vortexed for $3 \times 15 \mathrm{~s}$ with $0.5 \mathrm{~mL}$ glass beads

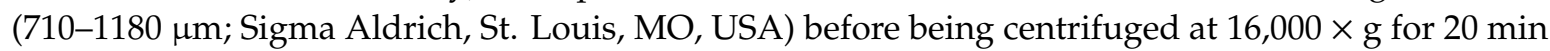
at $4{ }^{\circ} \mathrm{C}$. Pigments were then separated by reverse-phase HPLC, using Shimadzu Prominence HPLC system, comprising a DGU-20A5R Degassing Unit, a LC-20AT Liquid chromatograph, a SIL-20AC Autosampler, a CTO-10ASVP Column Oven and a SPD-M20A Diode Array Detector (Shimadzu, Kyoto, Japan). The HPLC column (Nova Pak C18, 60A column, $150 \mathrm{~mm}$ length and $4 \mu \mathrm{m}$ pore size) was eluted with a mobile phase gradient $\left(1 \mathrm{~mL} \mathrm{~min}^{-1}\right)$ set to the program described in [49]. Absorbance chromatograms were detected at $430 \mathrm{~nm}$ and quantified with pigments standards purchased from DHI Lab (Horstholm, Denmark). Acquisition and data treatment were performed using the Waters Empower software (Waters, Milford, MA, USA).

\subsection{Chlorophyll Fluorescence Measurements}

Chlorophyll fluorescence emission was measured using a DUAL-PAM 100 (Fiber version; Walz, Effeltrich, Germany), with the fiber optic fitted to a temperature-controlled chamber (50 mL volume; $25^{\circ} \mathrm{C}$ ). After a dark adaptation (DA) of $15 \mathrm{~min}$, a light saturation curve comprising six irradiance steps $\left(0,75,150,300,600\right.$ and $900 \mu \mathrm{mol}$ photon $\mathrm{m}^{-2} \mathrm{~s}^{-1}$; measured with a Submersible Spherical Micro Quantum Sensor (Walz) connected to a LI-250A light meter (Li-Cor)) of 5 min each was conducted, with gain $(\mathrm{G})$ and damping $(\mathrm{D})$ set to 5 and $1 \mathrm{~ms}$, respectively. The minimal fluorescence levels $\left(\mathrm{F}_{0}\right.$ in the dark and $F_{S}$ in the light) were determined by applying weak modulated pulses of red measuring light $(\mathrm{ML}=10)$. A $0.8 \mathrm{~s}$ saturating pulse of actinic light $(\mathrm{SI}=10$ corresponding to an intensity of $\approx 4000 \mu \mathrm{mol}$ photon $\mathrm{m}^{-2} \mathrm{~s}^{-1}$ ) was then applied at the end of each step to measure the maximum fluorescence level $\left(\mathrm{F}_{\mathrm{M}} ; \mathrm{F}_{\mathrm{M}}{ }^{\prime}\right.$ in the light). The maximum photochemical quantum yield of PSII $\left(\mathrm{F}_{\mathrm{V}} / \mathrm{F}_{\mathrm{M}}\right)$ was calculated at the end of the dark incubation as $\left(\mathrm{F}_{\mathrm{M}}-\mathrm{F}_{0}\right) / \mathrm{F}_{\mathrm{M}}$. The effective quantum yield of PSII ( $\Phi$ PSII) was calculated at the end of each light step as $\left(\mathrm{F}_{\mathrm{M}}{ }^{\prime}-\mathrm{F}_{\mathrm{S}}\right) / \mathrm{F}_{\mathrm{M}^{\prime}}$. The non-photochemical quenching (NPQ) was evaluated as $\left(\mathrm{F}_{\mathrm{M}}-\mathrm{F}_{\mathrm{M}^{\prime}}\right) / \mathrm{F}_{\mathrm{M}^{\prime}}$ and the relative electron transport rates $\left(\mu \mathrm{mol} \mathrm{e}^{-} \mathrm{m}^{-2} \mathrm{~s}^{-1}\right)$ through PSII $\left(\mathrm{rETR}_{\mathrm{PSII}}\right)$ were calculated as the product of actinic light intensity by the corresponding $\Phi$ PSII.

The relative flux of electrons originating from PSII that reduce $\mathrm{O}_{2}$ through the action of the oxygen-dependent chloroplastic alternative electron flows (Mehler reaction, chlororespiration, photorespiration ... ) has been estimated according to the methodology of [50] with slight modifications. Briefly, the $\mathrm{O}_{2}$-dependent rETR at the induction of photosynthesis was calculated as the difference between rETR $P$ PSI values in the presence and absence of $\mathrm{O}_{2}$. The rETR PSII was determined during the induction phase of photosynthesis and was measured at the end of an illuminated period of $15 \mathrm{~s}$ at an intensity of $340 \mu \mathrm{mol}$ photons $\mathrm{m}^{-2} \mathrm{~s}^{-1}$. The $\mathrm{O}_{2}$ depletion in the samples was obtained in $5 \mathrm{~min}$ using $50 \mathrm{mM}$ glucose, $200 \mathrm{U} \mathrm{mL}^{-1}$ glucose oxidase and $200 \mathrm{U} \mathrm{mL}^{-1}$ catalase.

\subsection{Oxygen Exchange Measurements}

Oxygen exchange rates were measured using a Clark-type electrode connected to a Strathkelvin 928 Oxygen System (Strathkelvin Instruments Ltd., North Lanarkshire, UK) and fitted to a temperature-controlled chamber $\left(50 \mathrm{~mL}\right.$ volume; $\left.25^{\circ} \mathrm{C}\right)$. The oxygen electrode was calibrated against 
air-saturated (100\% oxygen saturation) and sodium dithionite saturated ( $0 \%$ oxygen saturation) seawater. Actinic light was provided by LED light sources (LEDS-5MP/WS, Monacor, Bremen, Germany; color temperature of $5500 \mathrm{~K}$ ). Values at steady state were collected after 5 min illumination at each light intensity (as described for chl fluorescence measurements). Data were normalized to the surface area of the coral nubbins or to the endosymbiont concentration.

\subsection{Calcification and Ammonium Uptake Rates}

Calcification rates were measured on six coral nubbins in each treatment using the buoyant weight technique [51]. All results were normalized to skeletal surface area and expressed in $\%$ day $^{-1}$. The uptake rates of ammonium were determined by measuring the depletion of ammonium over time in ammonium-enriched beakers, 1, 3, 7, 11 and 21 days after the beginning of the experiment. Six coral nubbins per conditions were introduced in $250 \mathrm{~mL}$ beakers containing $200 \mathrm{~mL}$ FSW and a magnetic stirrer to ensure a complete homogenization of the medium. A beaker without coral served as a control for changes in ammonium concentrations that could be due to non-coral specific uptake. The beakers were then partially immerged in a water bath at $25{ }^{\circ} \mathrm{C}$ and exposed to a light intensity of $350 \mu \mathrm{mol}$ photon $\mathrm{m}^{-2} \mathrm{~s}^{-1}$. After $30 \mathrm{~min}$ of acclimatization, an enriched FSW solution containing $\mathrm{NH}_{4} \mathrm{Cl}$ was added to each beaker to reach an initial concentration of $5 \mu \mathrm{M} \mathrm{NH}_{4}{ }^{+}$. Then, $10 \mathrm{~mL}$ of water were sampled in each beaker immediately after enrichment and then every $10 \mathrm{~min}$ for $30 \mathrm{~min}$. Water was filtered through a $0.45 \mu \mathrm{m}$ syringe filter and ammonium concentration was determined with a Proxima autoanalyser (Alliance Instrument) and according to the method described in [42]. Uptake rates of ammonium were calculated as the difference between the initial and final concentrations, taking into account the diminution of the beaker volume, divided by the time, and standardized to coral surface area.

\subsection{Statistical Analysis}

Statistical analyses of the data were performed in SigmaPlot 11.0 (Systat Software, San José, CA, USA) or in Statistica 10 (StatSoft, Tulsa, OK USA). Principal component analyses (PCA) were performed on physiological parameters related to the holobiont (Symbiodinium density, ammonium uptake, respiration, Pmax and P/R) or to the symbiont (chlorophylls content, $\mathrm{F}_{\mathrm{V}} / \mathrm{F}_{\mathrm{M}}, \mathrm{rETR}$ PSII max, NPQ max and $\mathrm{O}_{2}$-dependent $\left.r E T R_{P S I}\right)$ after $\log (x+1)$ transformation. Then, the 'time', 'treatment' and 'time $x$ treatment' effects were examined by two-way repeated measures ANOVA (2W-rmANOVA). When significant differences were obtained for the 'time $x$ treatment' effect, the analysis was followed by the SNK's method for all pairwise multiple comparison. Prior to this analysis, the normality of data was confirmed with the Shapiro-Wilk test and data were arcsine square root transformed when required. The Mauchly's Test was used to assess the sphericity assumption (independency of the repeated measures), and F-value was adjusted by a Greenhouse-Geisser correction if the assumption was not fulfilled. Differences were considered statistically significant when $P<0.05$. All data were expressed as mean \pm SD. As we did not observe any significant variation for the physiological parameters investigated at days 1 and 3, and for more clarity, we only displayed data for days 7, 11 and 21 (see Sable $\mathrm{S} 1$ for values at the beginning of the experiment).

\section{Results}

PCA analyses were performed to compare the physiological traits of the corals and their endosymbionts maintained under the four conditions (Figure 1). These analyses showed a clear separation in the distribution of the data related to the holobiont physiology (Figure 1A), with the PC1 and PC2 explaining 60.3 and $26.1 \%$ of the total variance, respectively. The first axis (PC1) is mainly defined by the parameters related to photosynthesis-respiration ratio and to a lesser extent to the endosymbiont density. It clearly separates nitrogen-enriched conditions $(+\mathrm{iC}$ and $+\mathrm{iN} \& \mathrm{iC})$ from the two other treatments. The second component (PC2) is mainly correlated $(r=-0.784)$ with the $\mathrm{NH}_{4}{ }^{+}$uptake parameter, and again separates nitrogen-enriched conditions from the $+\mathrm{IC}$ condition. 
For the endosymbionts' physiological parameters (Figure 1B), the data are less clearly separated between treatments. The first two components (PC1 $=73.7 \%$ and PC2 $=16.6 \%$ ) explain $93.3 \%$ of the variance. PC1 is associated with chlorophylls concentrations $(r=0.951)$ and PC2 with photosynthetic performances (max rETR, $r=0.741$; $\max \mathrm{NPQ}, r=-0.608$ ).
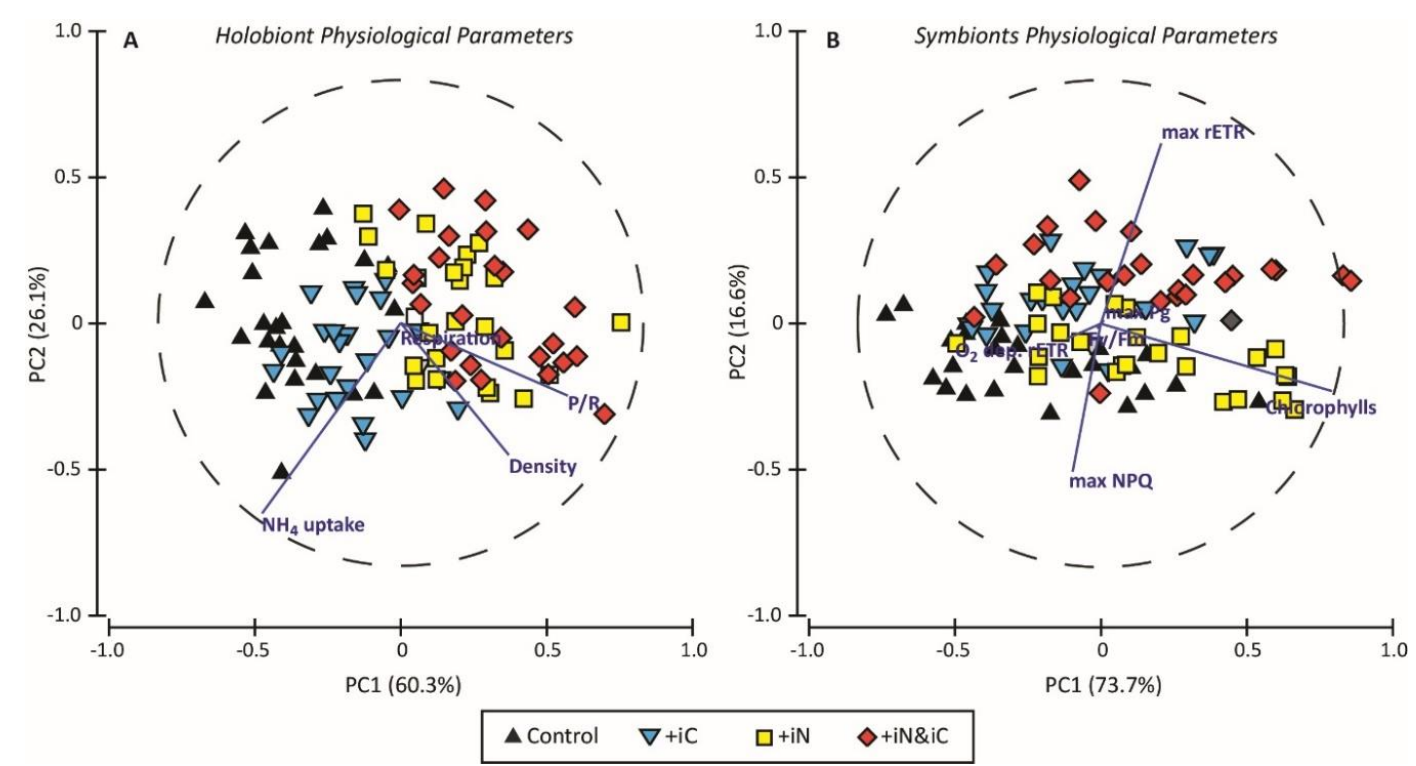

Figure 1. The principal component analyses bi-plots on parameters related to (A) the holobiont physiology and to (B) the symbiont physiology and photobiology. Black triangles, blue inverted triangles, yellow squares and red diamonds represent, respectively, $S$. pistillata nubbins exposed for 3 weeks to natural seawater (control) and to seawater enriched with $6 \mathrm{mM} \mathrm{HCO}_{3}{ }^{-}(+\mathrm{iC}), 4 \mu \mathrm{M} \mathrm{NH}_{4}{ }^{+}$ $(+\mathrm{iN})$, both $(+\mathrm{iC} \& \mathrm{iN})$. Blue lines represent the physiological traits used as descriptors.

\subsection{Effects of Increased Ammonium Supply Compared to Control Condition.}

The enrichment of seawater with $4 \mu \mathrm{M} \mathrm{NH}_{4}{ }^{+}$alone (measured concentrations of $4.36 \pm 1.23 \mu \mathrm{M}$; Table 1) significantly affected several physiological parameters of $S$. pistillata and its endosymbionts compared to the control condition. The Symbiodinium density was higher at day $7(P<0.05)$ and seemed to have reached a steady-state density with 3.32 and $3.38 \times 10^{6}$ cells cm$^{-2}$ (154 and $164 \%$ of the control) after 11 and 21 days of exposure to this treatment, respectively (Figure 2A). This higher Symbiodinium density coincided with an increase in chlorophyll and carotenoid content per endosymbionts and per skeletal surface area (Figure $2 \mathrm{~B}, \mathrm{D}$ and Figure S2). The total chlorophyll and carotenoid contents were higher than the controls after day 11 (Figure 2C,D; $P<0.05$ ) and day 7 (Figure 2B and Figure S2; $P<0.05)$, respectively, and remained higher until the end of the experiment. These statistical differences could be partly explained by the decrease in the total chlorophyll content in control corals after day 7 (Figure 2C,D). The Chl-a/Chl- $c_{2}$ ratio was not affected in the $\mathrm{NH}_{4}{ }^{+}$-enriched condition and was around two Chl- $a$ molecules per one Chl- $c_{2}$ molecule (Figure S3). However, after 3 weeks of treatment, the proportion of $\mathrm{Chl}-c_{2}$ was slightly increased in the control condition and hence the ratio was significantly lower $(P<0.001)$. As a result of the increase in Symbiodinium density and in photosynthetic pigments content from day 7 to day 21, the maximum gross photosynthesis $\mathrm{cm}^{-2}$ was enhanced between 58 and $73 \%$ comparatively to the controls (Figure $2 \mathrm{E} ; P<0.001$ ). While the values of maximum gross photosynthesis cell $^{-1}$ (Figure 2F) maximal photochemical quantum yield of PSII ( $\mathrm{F}_{\mathrm{V}} / \mathrm{F}_{\mathrm{M}}$; Figure S4) and non-photochemical quenching (NPQ; Figure 3C) remained relatively close to controls throughout the

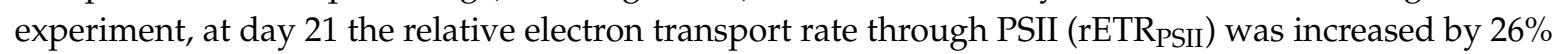
$(P=0.002)$ and the $\mathrm{O}_{2}$-dependent rETR was 1.6 times lower $(P<0.001$; Figure $3 \mathrm{~A}, \mathrm{~B})$. Calcification rate of corals supplied with ammonium increased significantly $(P=0.005)$, on average by $23 \%$ (Figure S5). 

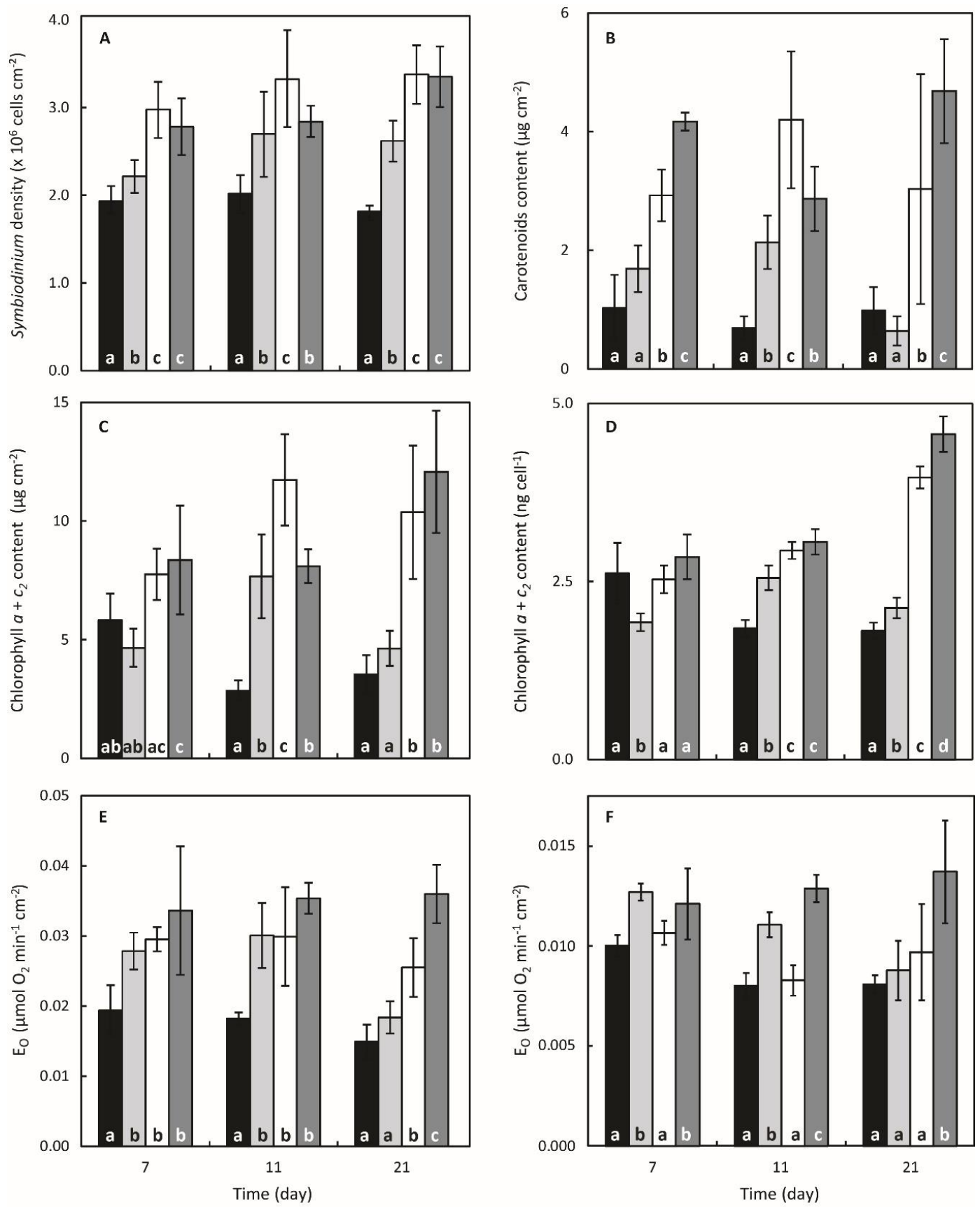

- Control $\square+\mathrm{iC} \square+\mathrm{iN} \square+\mathrm{iC \& iN}$

Figure 2. Evolution of the physiological parameters of the coral S. pistillata exposed for 3 weeks to natural seawater (control) and to seawater enriched with $6 \mathrm{mM} \mathrm{HCO}_{3}{ }^{-}(+\mathrm{iC})$ or $4 \mu \mathrm{M} \mathrm{NH}_{4}{ }^{+}(+\mathrm{iN})$ or both (+iC \& iN). (A) Symbiodinium densities $\left(\times 10^{6} \mathrm{cells}^{-1} \mathrm{~cm}^{-2}\right),(\mathbf{B})$ total carotenoids concentrations (peridinin + xanthophylls $+\beta$-carotene; $\left.\mu \mathrm{g} \mathrm{cm}^{-2}\right),(\mathrm{C})$ total chlorophylls concentrations $\left(a+c_{2} ; \mu \mathrm{g}\right.$

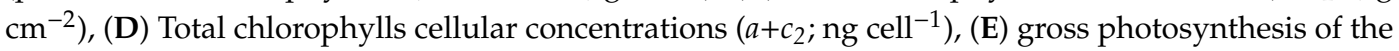
holobiont (gross $\mathrm{O}_{2}$ evolution by PSII ( $\left.\mathrm{E}_{\mathrm{O}}\right) ; \mu \mathrm{mol} \mathrm{O} \mathrm{Omin}^{-1} \mathrm{~cm}^{-2}$ ) measured at $600 \mu \mathrm{mol}$ photons $\mathrm{m}^{-2}$ $\mathrm{s}^{-1},(\mathrm{~F})$ gross photosynthesis of the symbionts $\left(\mathrm{fmol} \mathrm{O}_{2} \mathrm{~min}^{-1}\right.$ cell $\left.{ }^{-2}\right)$. Data are presented as mean \pm $\mathrm{SD}(n=6)$. Different letters indicate statistically significant differences between each treatment for one time point $(P<0.05)$. 

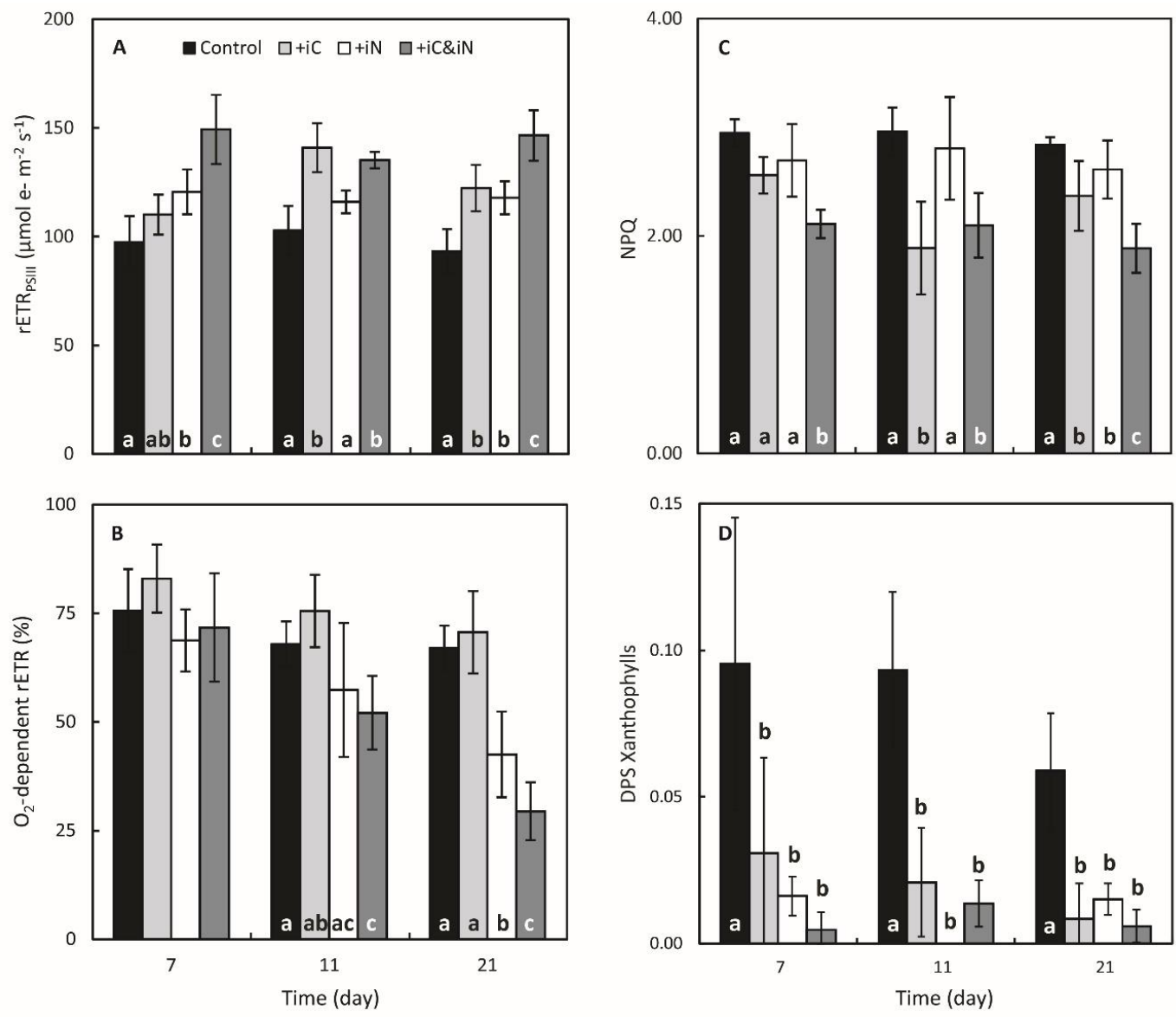

Figure 3. Evolution of the photosynthetic parameters of the endosymbionts of S. pistillata exposed for 3 weeks to natural seawater (control) and to seawater enriched with $6 \mathrm{mM} \mathrm{HCO}_{3}{ }^{-}(+\mathrm{iC})$ or $4 \mu \mathrm{M} \mathrm{NH}_{4}{ }^{+}$ $(+\mathrm{iN})$ or both $(+\mathrm{iC} \& \mathrm{iN})$. (A) the relative electron transport rate through PSII $\left(\mathrm{rETR}_{\mathrm{PSII}} ; \mu \mathrm{mol} \mathrm{e}^{-} \mathrm{m}^{-2}\right.$ $\mathrm{s}^{-1}$ ) at $600 \mu \mathrm{mol}$ photons $\mathrm{m}^{-2} \mathrm{~s}^{-1}$, (B) the $\mathrm{O}_{2}$-dependent rETR at the induction of photosynthesis (\%), (C) the non-photochemical quenching (NPQ) at $600 \mu \mathrm{mol}$ photons $\mathrm{m}^{-2} \mathrm{~s}^{-1}$ and, (D) the de-epoxidation state of the xanthophylls cycle (DPS; was measured after 15 min of illumination with $400 \mu \mathrm{mol}$ photons $\mathrm{m}^{-2} \mathrm{~s}^{-1}$ as the ratio of Diatoxanthin (Dtx) to Diadinoxanthin (Ddx) + Dtx. Data are presented as mean $\pm \mathrm{SD}(n=6)$. Different letters indicate statistically significant differences between each treatment for one time point $(P<0.05)$.

\subsection{Effects of the Increased Bicarbonate Supply Compared to Control Condition}

The increased availability in bicarbonate alone (6 vs. $2 \mathrm{mM}$; Table 1 ) in the iC treatment positively impacted several physiological parameters of the holobiont compared to the control condition. Symbiodinium density was slightly higher at day $7(P=0.048)$ and increased up to a density of $2.62 \pm 0.23 \times 10^{6}$ cells cm${ }^{-2}$ at day 21 (144\% increase; $P<0.001$; Figure $\left.2 \mathrm{~A}\right)$. Rates of gross photosynthesis expressed per surface area differed significantly from the controls at day 7 and 11 $(P=0.003, P<0.001)$ and increased to $0.028 \pm 0.003$ and $0.030 \pm 0.005 \mu \mathrm{mol} \mathrm{O} \mathrm{min}^{-1} \mathrm{~cm}^{-2}(147$ and $166 \%$ increase), respectively (Figure $2 \mathrm{E}$; similar observations can be made on rates of gross

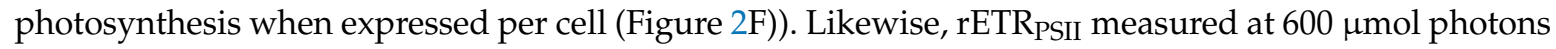
$\mathrm{m}^{-2} \mathrm{~s}^{-1}$ increased significantly by about one third after day $11(P<0.001$; Figure $3 \mathrm{~A})$. NPQ declined strongly at day $11(P<0.001$; Figure $3 C)$ but the difference of the means between controls and treated samples at day 21 was lower but yet significant $(P=0.031)$. The NPQ decline is consistent with the lower de-epoxidation state of the xanthophylls observed from day $7(P<0.05$; Figure 3D). Corals also calcified more in this condition compared to the controls (av. 34\%; $P<0.001$; Figure S5). 


\subsection{Effects of the Combined Supply of Ammonium and Bicarbonate Compared to All Conditions}

The enrichment of seawater with both $6 \mathrm{mM} \mathrm{HCO}_{3}{ }^{-}$and $4 \mu \mathrm{M}$ of $\mathrm{NH}_{4}{ }^{+}$resulted in a $40 \%$ increase of the Symbiodinium density, at day 7 and $11(P=0.002$ and $P<0.001$, respectively), and $85 \%$ on average at day $21(P<0.001)$. On the last day of the experiment, the average density in this treatment was higher than in the samples of the iC treatment alone but was similar to that of the iN treatment $(P<0.001$; Figure 2A). The total chlorophylls and carotenoids content expressed per coral surface (Figure 2B,C) or symbiont cell (Figure 2D and Figure S2) significantly increased throughout the experiment. After 21 days of treatment, $\mathrm{Chl} a+c_{2}$ reached a concentration of $4.57 \pm 0.25 \mathrm{ng} \mathrm{cell}^{-1}$ $\left(12.07 \pm 2.58 \mu \mathrm{g} \mathrm{cm}^{-2}\right)$ and was significantly higher than in all other treatments (Figure 2D; $\left.P<0.001\right)$. Similarly to the iN treatment, the $\mathrm{Chl}-a / \mathrm{Chl}-c_{2}$ ratio remained stable during the experiment but significantly higher than the other treatments $(P<0.05$; Figure S3). Globally, corals nubbins in the iC $\&$ iN treatment were also those that had the highest photosynthetic activity with: a maximum gross photosynthesis per symbiont cell that were respectively 1.7, 1.6 and 1.4 times higher than the control, iC and iN treatments, respectively $(P<0.05$; Figure $2 \mathrm{E}, \mathrm{F})$; a relative electron transport rate through PSII 25 to $50 \%$ quicker on average $(P<0.001$; Figure $3 \mathrm{~A})$; a NPQ significantly reduced by 20 to $30 \%(P<0.001$; Figure 3C); and a de-epoxidation state of the xanthophylls (Figure 3D) an order of magnitude lower than the control $\left(P<0.001\right.$; Figure 3D) but similar to the two other treatments. The $\mathrm{O}_{2}$-dependent rETR at the induction of photosynthesis decreased significantly from $72 \pm 12 \%$ at day 7 to $29 \pm 7 \%$ at day 21 in samples enriched with both ammonium and bicarbonate compared to control, iC, and iN samples $\left(P<0.05\right.$; Figure 3B). Figure 4 illustrates photosynthesis-irradiance curves where rETR ${ }_{\mathrm{PSII}}$ was evaluated in parallel with gross $\mathrm{O}_{2}$ evolution by PSII $\left(\mathrm{E}_{\mathrm{O}}\right)$ at steady state of photosynthesis. This method has been successfully applied in the past to evaluate the magnitude of oxygen-dependent chloroplastic alternative electron flows (AEF; e.g., Mehler reaction, chlororespiration, photorespiration ... ) in various species of Symbiodiniaceae isolated in culture [52,53]. In the present study, rETR PSII and $E_{O}$ both saturated at light intensities above $300 \mu \mathrm{mol}$ photons $\mathrm{m}^{-2} \cdot \mathrm{s}^{-1}$ and $600 \mu \mathrm{mol}$ photons $\mathrm{m}^{-2} \cdot \mathrm{s}^{-1}$ at the beginning of the experiment and after 3 weeks of bicarbonate and ammonium supplementation, respectively (Figure S6). However the shape of the relationship between both parameters (i.e., linear) differed from those previously reported in [53] and more recently in [52] (i.e., non-linear with net $\mathrm{VO}_{2}$ saturating more rapidly than $\left.\mathrm{rETR}_{\mathrm{PSII}}\right)$. Finally, the calcification rate measured in the $\mathrm{iC} \& \mathrm{iN}$ condition was also higher than in the control condition $(P=0.006$; Figure S5) but similar to the rates measured in the other experimental treatments.

\section{Discussion}

This study reports the first assessment of a combined inorganic carbon $\left(\mathrm{HCO}_{3}{ }^{-}\right)$and nitrogen $\left(\mathrm{NH}_{4}{ }^{+}\right)$enrichment on the physiological traits of a coral-dinoflagellate symbiosis. Although positive effects on coral physiology could already be observed with the supplementation of one or the other nutrient, the most important and positive changes were observed when both nutrients were provided, due to an interactive relationship between $\mathrm{NH}_{4}{ }^{+}$and DIC acquisition. These results suggest that coral symbionts are co-limited in nitrogen and carbon for an optimal photosynthesis.

\subsection{The Increased Availability of $\mathrm{HCO}_{3}{ }^{-}$and $\mathrm{NH}_{4}{ }^{+}$Improves Photosynthetic Processes in Endosymbionts}

The increased availability in bicarbonate or ammonium alone had significant, but time-dependent effects on symbiont physiology. Since symbionts are generally nitrogen limited in hospite [54], ammonium supplementation induced a fast response of the symbionts, which showed a significant increase in growth and pigment content as well as an increase in some of their photosynthetic processes ( $E_{O}$ per symbiont and rETR) after only 7 days of incubation. Conversely, the rate at which iC supplementation affected symbiont physiology was dependent on the parameter considered. Nevertheless, after 21 days, the increased availability in either bicarbonate or ammonium improved significantly the photosynthetic efficiency $\left(r E T R_{\text {PSII }}\right)$ and/or capacity $\left(\mathrm{O}_{2}\right.$ production per symbiont 
cell) of the endosymbionts of S. pistillata (Figures $3 \mathrm{~A}$ and $2 \mathrm{~F}$ ), partly due to a significant increase in chlorophylls content per cell. This suggests that the activity of the photosynthetic apparatus is impacted by the nitrogen availability and that the in hospite symbionts are $\mathrm{CO}_{2}$ limited. The positive effect of bicarbonate supplementation also translated into a significant decrease in NPQ and DPS xanthophylls (Figure 3). These results are indicative of lower excitation pressure on Symbiodinium's photosynthetic apparatus in the enriched conditions (see below for more explanations). A DIC limitation of in hospite symbionts is in agreement with previous studies, which reported an increase in photosynthesis per symbiont cell or chlorophyll content $[15,20,21]$. Tansik et al. [15] postulated that the cause of such DIC limitation of photosynthesis might be related to the activity of the coral external carbonic anhydrase and therefore, to the host regulation of DIC delivery to endosymbionts.

The major finding of this study is the co-limitation of symbiont photosynthesis by inorganic nitrogen and carbon. Indeed, several symbiont parameters, such as the chl and carotenoid content per cell, the rates of oxygen production per cell and the rETR were significantly higher under the double iC \& iN enrichment compared to all other conditions after 21 days of incubation (Figure 2D,F, Figure S2 and Figure 3A). Concomitantly, symbionts showed the highest decrease in NPQ (ca. 30\% Figure 3C) and a constant low de-epoxidation state of the xanthophylls compared to control (Figure 3D). These results suggest that the excitation pressure on Symbiodinium's photosynthetic apparatus in the enriched conditions is lower and more energy is allocated to photochemistry. The 50\% reduction in the $\mathrm{O}_{2}$-dependent rETR at the induction of photosynthesis (Figure 3B) comes in support to this hypothesis. Indeed, the $\mathrm{O}_{2}$-dependent rETR is a parameter estimating the amplitude of AEF involving $\mathrm{O}_{2}$ as the final electron acceptor, and has been demonstrated to be related to the Mehler reaction (i.e., electrons originating from PSII that reduce $\mathrm{O}_{2}$ at the PSI acceptor side) in Symbiodiniaceae [30]. As the Mehler-reaction acts as a photoprotective mechanism, a decrease of $\mathrm{O}_{2}$-dependent $\mathrm{rETR}$ is indicative of an increased availability of electron acceptors downstream PSI. The evolution of the relationship between rETR PSII $_{\text {and the }} \mathrm{O}_{2}$ net exchange rates during steady state photosynthesis (Figure 4) is also consistent with the above results. Such relationship became more linear at the highest light intensities (> $300 \mu \mathrm{mol}$ photons $\mathrm{m}^{-2} \cdot \mathrm{s}^{-1}$ ) after 3 weeks of the double iC \& iN enrichment suggesting that coral symbionts have a more efficient light phase, very likely because more electron acceptors downstream PSI are available at the induction of photosynthesis and during steady state. It also suggests that rapid variations in light intensity (e.g., underwater light flecks) and the excess energy that co-occurs, could be more easily withstood by the photosynthetic apparatus of the endosymbionts.

The coupling between photosynthesis and nitrogen metabolism is well-known in microalgae [55]. Since $\mathrm{N}$ is involved in the composition of photosynthetic pigments like chlorophylls and phycobilins, $\mathrm{N}$ limitation was shown to change the ratio of chlorophyll- $a$ to accessory pigments, to cause a reduction in thylakoid absorptivity, to negatively impact photosynthetic enzymes such as Rubisco, as well as the efficiency of energy transfer through the photosynthetic chain (reviewed in [56]). In corals, once ammonium is absorbed by the endosymbionts, it is assimilated into glutamate and glutamine thanks to the glutamine synthetase (GS)/glutamate synthase (GOGAT) cycle [57]. This metabolic pathway is driven by energy and reducing power derived from photosynthesis (reduced Ferredoxin, ATP and $\mathrm{NAD}(\mathrm{P}) \mathrm{H})$ ) and the synthesized products are the precursors for the biosynthesis of major $\mathrm{N}$ compounds (amino acids, nucleic acids, chlorophylls, secondary metabolites ... ) [58]. All together these results suggest that the increased availability of both $\mathrm{HCO}_{3}{ }^{-}$and $\mathrm{NH}_{4}{ }^{+}$improves the photosynthetic efficiency and capacity by providing more electron sinks through the Calvin-Benson cycle and the ammonium assimilation pathway. Moreover, by positive feedback, the resulting higher photosynthetic activity provides more carbon molecules onto which nitrogen can be fixed and thus impacts positively the symbiont biomasses. 

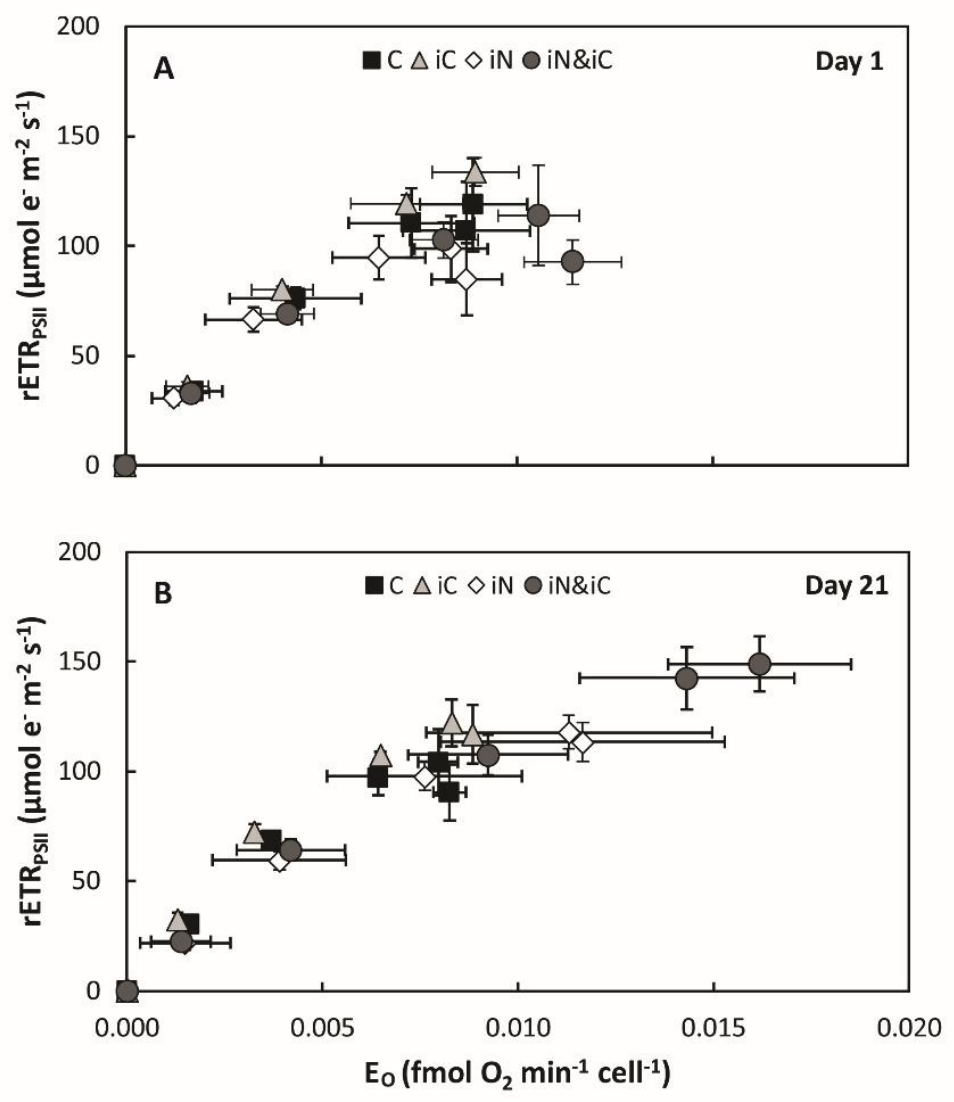

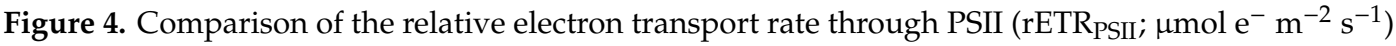
and gross $\mathrm{O}_{2}$ evolution by PSII $\left(\mathrm{E}_{\mathrm{O}} ; \mathrm{fmol}_{2} \mathrm{~min}^{-1}\right.$ cell $\left.^{-1}\right)$ at steady-state photosynthesis in S. pistillata, after 1 day (A) and 3 weeks (B) of exposure to natural seawater (control) and to seawater enriched with $6 \mathrm{mM} \mathrm{HCO}_{3}{ }^{-}(+\mathrm{iC})$ or $4 \mathrm{\mu M} \mathrm{NH}_{4}{ }^{+}(+\mathrm{iN})$ or both $(+\mathrm{iC} \& \mathrm{iN})$. Measurements were conducted at 0,70 , $150,300,600$ and $900 \mu \mathrm{mol}$ photons $\mathrm{m}^{-2} \cdot \mathrm{s}^{-1}$ and data are presented as mean $\pm \operatorname{SD}(n=6)$.

\subsection{The Increased Availability of $\mathrm{HCO}_{3}{ }^{-}$and $\mathrm{NH}_{4}{ }^{+}$Sustains the Growth of the Holobiont}

When expressed per unit of coral surface area, gross photosynthesis rates, which are now a proxy of the total amount of photosynthetic carbon acquired by the holobiont, were increased in all enriched conditions (Figure 2E). Such a response at the holobiont level has been previously reported on $S$. pistillata when supplemented with bicarbonate [59] or ammonium [33,34,36]. In our study it is related to the increased symbiont biomass that occurred within a week. While symbiont growth limitation by nitrogen availability is relatively well-known (e.g., [33,35,37,60,61]) it has been less reported for $\mathrm{CO}_{2} / \mathrm{HCO}_{3}{ }^{-}$availability, alone or in combination with iN, which is a new observation in coral studies. The stimulation of symbiont growth observed here suggests that the enhancement of photosynthesis is accompanied by a higher carbon fixation in the symbionts. A co-limitation of primary productivity by carbon and nitrogen has been well studied in terrestrial plants and macroalgae. In these models, it was demonstrated that $\mathrm{N}$ uptake and assimilation rates were significantly enhanced following culture at high $\mathrm{pCO}_{2}$ (e.g., [62-64]). The increased demand in mineral nutrients such as nitrogen and phosphorus is generally needed to support a higher growth rates of plants and algae under high iC availability. It has to be noticed that the uptake rates of iN observed in the present study were also always higher under the control and iC enrichments (Figure S1), suggesting higher needs in iN under these two conditions; however, since the uptake rates of iN were measured at the holobiont level (host + symbionts + microbiome), we cannot conclude about the occurrence of a similar effect in coral endosymbionts. In addition, a meta-analysis on plants demonstrated that high iC levels significantly decreased nitrogen concentrations in plant tissues by 2 to $57 \%$ depending on species, as a consequence 
of a combination of increase carbohydrate concentrations, starch accumulation, decreased investment in Rubisco, and changes in tissue chemical composition (reviewed in [65]). Although this remains to be tested, similar changes might have occurred in our coral symbiosis following iC enrichment, which have requested higher nitrogen acquisition by the symbionts, only possible, in oligotrophic waters, with an additional input of iN. In turn, the increased nitrogen input has promoted Symbiodinium proliferation within host tissues, resulting very likely in a greater competition for $\mathrm{CO}_{2} / \mathrm{HCO}_{3}{ }^{-}$between individual endosymbiotic cells [66]. Therefore, when $\mathrm{CO}_{2}$ is provided concomitantly with nitrogen, photosynthetic rates at the symbiont and the holobiont levels are further improved.

The enhancement of areal gross photosynthesis does not necessarily result in enhanced carbon translocation into the host tissue, and thus enhanced host benefit. This is due to the fact that growing symbiont populations might turn into parasitism (keeping nutrients for their own needs) under certain conditions such as thermal stress or nutrient enrichment [67-69]. The impact of nutrient enrichment on the coral-algae symbiosis is however dependent on the forms (organic versus inorganic, ammonium versus nitrate) and nitrogen:phosphorus ratio [29,70]. Although nutrient supply in the form of plankton particles or ammonium, increases both the areal rates of photosynthesis and of carbon translocation in the same S. pistillata species than as used here [71,72], no study has investigated the effect of a double enrichment in inorganic carbon and nitrogen on the translocation rates of photosynthates. Nevertheless, the fact that calcification rates were similarly increased in all enriched treatments (either with iC, iN or iN $\& \mathrm{iC})$ compared to the control conditions suggest that the improvement in the photosynthetic efficiency of the symbionts, and the overall increase in the areal rates of photosynthesis benefit to the coral host. Indeed, calcification is an energy-demanding process, which cannot be achieved under sub-optimal nutritional conditions [73]. Some previous studies actually linked increased calcification rates with high bicarbonate/carbonate concentrations $[20,57,74]$. They explained the effect by the establishment of a high aragonite saturation state ( $\Omega$ aragonite), favorable for calcification, or by a suppression of competition between calcification and photosynthesis for iC. However, the results obtained here with iN enrichment alone suggest that the enhancement of calcification in our experiment was not linked to a higher $\Omega$ aragonite, or to a direct nitrogen or carbon effect on the calcification process, but rather to higher rates of photosynthesis, which provided more energy, as well as organic molecules for the synthesis of the organic matrix of the coral skeleton [75]. As previously observed [76], the increase in calcification rate under the iC\&iN enrichment was much lower than the photosynthetic increase $(22 \%$ against $133 \%$ ), suggesting that coral calcification was already at a sub-optimal rate under non enriched conditions or that it was limited by other factors, independent of the photosynthetic process.

Eutrophication, with excessive amount of $\mathrm{N}, \mathrm{P}$, and $\mathrm{CO}_{2}$, and insufficient amount of dissolved $\mathrm{O}_{2}$, is becoming a serious problem causing a global deterioration of reef environments [77,78]. Our results however suggest that there is an interactive effect of high $\mathrm{iC}$ and $\mathrm{iN}$ on the photosynthesis and general metabolism of scleractinian corals like S. pistillata which will have to be further studied. In particular, it is well-known that nitrate, which is the main by-product of eutrophication, has a different effect on coral metabolism than ammonium [29,30,70,71], in particular under low phosphorus availability. Future studies should therefore aim to investigate the combined effects of all these nutrients when considered under their different forms and availabilities.

Supplementary Materials: The following are available online at http://www.mdpi.com/2076-2607/8/5/640/s1, Figure S1: Evolution of the ammonium uptake by S. pistillata, Figure S2: Evolution of the carotenoids cellular concentrations (peridinin + xanthophylls $+\beta$-carotene; $\mathrm{ng}$ cell ${ }^{-1}$ ) in the endosymbionts of the coral S. pistillata, Figure S3: Evolution of the chl-a/c 2 ratio in endosymbionts of the coral S. pistillata, Figure S4: Evolution of the maximal photochemical quantum yield $\left(\mathrm{F}_{\mathrm{V}} / \mathrm{F}_{\mathrm{M}}\right)$ of $S$. pistillata, Figure S5: Evolution of the calcification rates of

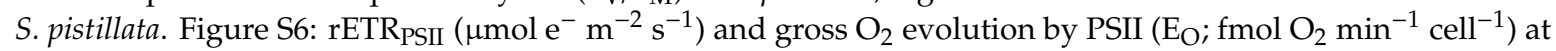
steady-state photosynthesis in S. pistillata,

Author Contributions: Conceptualization, S.R., C.F.-P.; data curation, S.R.; formal analysis, S.R.; funding acquisition, C.F.-P.; methodology, S.R.; Investigation, S.R., E.B., R.G.; writing-original draft, S.R., E.B., R.G. and C.F.-P.; writing-review and editing, S.R. and C.F.-P. All authors have read and agreed to the published version of the manuscript. 
Funding: This research received no external funding.

Acknowledgments: We would like to thank Cécile Rottier and Antoine Labbe for their technical assistance during this study and the reviewers for their useful comments.

Conflicts of Interest: The authors declare no conflict of interest.

\section{References}

1. Melo Clavijo, J.; Donath, A.; Serôdio, J.; Christa, G. Polymorphic adaptations in metazoans to establish and maintain photosymbioses. Biol. Rev. 2018, 93, 2006-2020. [CrossRef] [PubMed]

2. LaJeunesse, T.C.; Parkinson, J.E.; Gabrielson, P.W.; Jeong, H.J.; Reimer, J.D.; Voolstra, C.R.; Santos, S.R. Systematic revision of Symbiodiniaceae highlights the antiquity and diversity of coral endosymbionts. Curr. Biol. 2018, 28, 2570-2580.e6. [CrossRef] [PubMed]

3. Muscatine, L.; Porter, J.W. Reef corals: Mutualistic symbioses adapted to nutrient-poor environments. Bioscience 1977, 27, 454-460. [CrossRef]

4. Knowlton, N.; Brainard, R.E.; Fisher, R.; Moews, M.; Plaisance, L.; Caley, M.J. Coral reef biodiversity. In Life in the World's Oceans: Diversity Distribution and Abundance; Blackwell Publishing Ltd.: Hoboken, NJ, USA, 2010; pp. 65-74.

5. Venn, A.A.; Loram, J.E.; Douglas, A.E. Photosynthetic symbioses in animals. J. Exp. Bot. 2008, 59, $1069-1080$. [CrossRef]

6. Kopp, C.; Pernice, M.; Domart-Coulon, I.; Djediat, C.; Spangenberg, J.; Alexander, D.; Hignette, M.; Meziane, T.; Meibom, A. Highly dynamic cellular-level response of symbiotic coral to a sudden increase in environmental nitrogen. MBio 2013, 4. [CrossRef]

7. Falkowski, P.; Dubinsky, Z.; Muscatine, L. Light and the bioenergetics of a symbiotic coral. Bio Sci. 1984, 34, 705-709. [CrossRef]

8. Tremblay, P.; Grover, R.; Maguer, J.F.; Legendre, L.; Ferrier-Pagès, C. Autotrophic carbon budget in coral tissue: A new ${ }^{13} \mathrm{C}$-based model of photosynthate translocation. J. Exp. Biol. 2012, 215, 1384-1393. [CrossRef]

9. Gibbin, E.; Banc-Prandi, G.; Fine, M.; Comment, A.; Meibom, A. A method to disentangle and quantify host anabolic turnover in photosymbiotic holobionts with subcellular resolution. Commun. Biol. 2020, 3, 14. [CrossRef]

10. Wang, J.T.; Douglas, A.E. Nitrogen recycling or nitrogen conservation in an alga-invertebrate symbiosis? J. Exp. Biol. 1998, 201, 2445-2453.

11. Yellowlees, D.; Rees, T.A.V.; Leggat, W. Metabolic interactions between algal symbionts and invertebrate hosts. Plant Cell Environ. 2008, 31, 679-694. [CrossRef]

12. Krueger, T.; Bodin, J.; Horwitz, N.; Loussert-Fonta, C.; Sakr, A.; Escrig, S.; Fine, M.; Meibom, A. Temperature and feeding induce tissue level changes in autotrophic and heterotrophic nutrient allocation in the coral symbiosis - A NanoSIMS study. Sci. Rep. 2018, 8, 12710. [CrossRef] [PubMed]

13. Bertucci, A.; Moya, A.; Tambutté, S.; Allemand, D.; Supuran, C.T.; Zoccola, D. Carbonic anhydrases in anthozoan corals-A review. Bioorganic Med. Chem. 2013, 21, 1437-1450. [CrossRef] [PubMed]

14. Tansik, A.; Fitt, W.; Hopkinson, B. External carbonic anhydrase in three Caribbean corals: Quantification of activity and role in $\mathrm{CO}_{2}$ uptake. Coral Reefs 2015, 34, 703-713. [CrossRef]

15. Tansik, A.L.; Fitt, W.K.; Hopkinson, B.M. Inorganic carbon is scarce for symbionts in scleractinian corals. Limnol. Oceanogr. 2017, 62, 2045-2055. [CrossRef]

16. Zoccola, D.; Ganot, P.; Bertucci, A.; Caminiti-Segonds, N.; Techer, N.; Voolstra, C.R.; Aranda, M.; Tambutté, E.; Allemand, D.; Casey, J.R. Bicarbonate transporters in corals point towards a key step in the evolution of cnidarian calcification. Sci. Rep. 2015, 5, 9983. [CrossRef]

17. Barott, K.L.; Venn, A.A.; Perez, S.O.; Tambutté, S.; Tresguerres, M. Coral host cells acidify symbiotic algal microenvironment to promote photosynthesis. Proc. Natl. Acad. Sci. 2015, 112, 607-612. [CrossRef]

18. Leggat, W.; Badger, M.R.; Yellowlees, D. Evidence for an inorganic carbon-concentrating mechanism in the symbiotic dinoflagellate Symbiodinium sp. Plant Physiol. 1999, 121, 1247-1255. [CrossRef]

19. Brading, P.; Warner, M.E.; Smith, D.J.; Suggett, D.J. Contrasting modes of inorganic carbon acquisition amongst Symbiodinium (Dinophyceae) phylotypes. New Phytol. 2013, 200, 432-442. [CrossRef]

20. Herfort, L.; Thake, B.; Taubner, I. Bicarbonate stimulation of calcification and photosynthesis in two hermatypic corals. J. Phycol. 2008, 44, 91-98. [CrossRef] 
21. Goiran, C.; Al-Moghrabi, S.; Allemand, D.; Jaubert, J. Inorganic carbon uptake for photosynthesis by the symbiotic coral/dinoflagellate association I. Photosynthetic performances of symbionts and dependence on sea water bicarbonate. J. Exp. Mar. Biol. Ecol. 1996, 199, 207-225. [CrossRef]

22. Buxton, L.; Badger, M.; Ralph, P. Effects of moderate heat stress and dissolved inorganic carbon concentration on photosynthesis and respiration of Symbiodinium sp. (Dinophyceae) in culture and in symbiosis. J. Phycol. 2009, 45, 357-365. [CrossRef] [PubMed]

23. Rivers, J.S.; Peckol, P. Interactive effects of nitrogen and dissolved inorganic carbon on photosynthesis, growth, and ammonium uptake of the macroalgae Cladophora vagabunda and Gracilaria tikvahiae. Mar. Biol. 1995, 121, 747-753. [CrossRef]

24. Di Martino Rigano, V.; Vona, V.; Di Martino, C.; Rigano, C. Effect of darkness and $\mathrm{CO}_{2}$ starvation on NH4+ and $\mathrm{NO}_{3}-$ assimilation in the unicellular alga Cyanidium caldarium. Physiol. Plant. 1986, 68, 34-38. [CrossRef]

25. Gordillo, F.J.; Jimenez, C.; Figueroa, F.L.; Niell, F.X. Influence of elevated $\mathrm{CO}_{2}$ and nitrogen supply on the carbon assimilation performance and cell composition of the unicellular alga Dunaliella viridis. Physiol. Plant. 2003, 119, 513-518. [CrossRef]

26. Stitt, M.; Krapp, A. The interaction between elevated carbon dioxide and nitrogen nutrition: The physiological and molecular background. Plant Cell Environ. 1999, 22, 583-621. [CrossRef]

27. Zheng, Z.-L. Carbon and nitrogen nutrient balance signaling in plants. Plant Signaling $\mathcal{E}$ Behavior 2009, 4, 584-591.

28. Henley, W.J.; Levavasseur, G.; Franklin, L.A.; Osmond, C.B.; Ramus, J. Photoacclimation and photoinhibition in Ulva rotundata as influenced by nitrogen availability. Planta 1991, 184, 235-243. [CrossRef]

29. Shantz, A.A.; Burkepile, D.E. Context-dependent effects of nutrient loading on the coral-algal mutualism. Ecology 2014, 95, 1995-2005. [CrossRef]

30. D'Angelo, C.; Wiedenmann, J. Impacts of nutrient enrichment on coral reefs: New perspectives and implications for coastal management and reef survival. Curr. Opin. Environ. Sustain. 2014, 7, 82-93. [CrossRef]

31. Ferrier-Pagès, C.; Rottier, C.; Beraud, E.; Levy, O. Experimental assessment of the feeding effort of three scleractinian coral species during a thermal stress: Effect on the rates of photosynthesis. J. Exp. Mar. Biol. Ecol. 2010, 390, 118-124. [CrossRef]

32. Béraud, E.; Gevaert, F.; Rottier, C.; Ferrier-Pagès, C. The response of the scleractinian coral Turbinaria reniformis to thermal stress depends on the nitrogen status of the coral holobiont. J. Exp. Biol. 2013, 216, 2665-2674. [CrossRef] [PubMed]

33. Ferrier-Pages, C.; Gattuso, J.P.; Dallot, S.; Jaubert, J. Effect of nutrient enrichment on growth and photosynthesis of the zooxanthellate coral Stylophora pistillata. Coral Reefs 2000, 19, 103-113. [CrossRef]

34. Hoegh-Guldberg, O; Smith, G.J. Influence of the population-density of zooxanthellae and supply of ammonium on the biomass and metabolic characteristics of the reef corals Seriatopora hystrix and Stylophora pistillata. Mar. Ecol. Prog. Ser. 1989, 57, 173-186. [CrossRef]

35. Muscatine, L.; Falkowski, P.G.; Dubinsky, Z.; Cook, P.A.; McCloskey, L.R. The effect of external nutrient resources on the population dynamics of dooxanthellae in a reef coral. Proc. R. Soc. London Ser. B-Biol. Sci. 1989, 236, 311-324.

36. Dubinsky, Z.; Stambler, N.; Ben-Zion, M.; McCloskey, L.; Muscatine, L.; Falkowski, P. The effect of external nutrient resources on the optical properties and photosynthetic efficiency of Stylophora pistillata. Proc. R. Soc. Lond. B 1990, 239, 231-246.

37. Stambler, N.; Popper, N.; Dubinsky, Z.; Stimson, J. Effects of nutrient enrichment and water motion on the coral Pocillopora damicornis. Pac. Sci. 1991, 45, 299-307.

38. Fabricius, K.E. Effects of terrestrial runoff on the ecology of corals and coral reefs: Review and synthesis. Mar. Pollut. Bull. 2005, 50, 125-146. [CrossRef]

39. Szmant, A.M. Nutrient enrichment on coral reefs: Is it a major cause of coral reef decline? Estuaries 2002, 25, 743-766. [CrossRef]

40. Hoegh-Guldberg, O.; Mumby, P.J.; Hooten, A.J.; Steneck, R.S.; Greenfield, P.; Gomez, E.; Harvell, C.D.; Sale, P.F.; Edwards, A.J.; Caldeira, K.; et al. Coral reefs under rapid climate change and ocean acidification. Science 2007, 318, 1737-1742. [CrossRef] 
41. Weis, V.M. Effect of dissolved inorganic carbon concentration on the photosynthesis of the symbiotic sea-anemone Aiptasiapulchella C arlgren - role of carbonic-anhydrase. J. Exp. Mar. Biol. Ecol. 1993, 174, 209-225. [CrossRef]

42. Holmes, R.M.; Aminot, A.; Kérouel, R.; Hooker, B.A.; Peterson, B.J. A simple and precise method for measuring ammonium in marine and freshwater ecosystems. Can. J. Fish. Aquat. Sci. 1999, 56, 1801-1808. [CrossRef]

43. Lewis, E.; Wallace, D.; Allison, L.J. Program Developed for $\mathrm{CO}_{2}$ System Calculations; Carbon Dioxide Information Analysis Center, Managed by Lockheed Martin Energy Research Corporation for the US Department of Energy: Oak Ridge, TN, USA, 1998.

44. Dickson, A.; Millero, F. Short-term exposure to hypercapnia does not compromise feeding, acid-base balance or respiration of Patella vulgata but surprisingly is accompanied by radula damage. Deep-Sea Research 1987, 34, 1733-1743. [CrossRef]

45. Dickson, A.G. Standard potential of the reaction: $\mathrm{AgCl}(\mathrm{s})+12 \mathrm{H} 2(\mathrm{~g})=\mathrm{Ag}(\mathrm{s})+\mathrm{HCl}(\mathrm{aq})$, and and the standard acidity constant of the ion HSO4- in synthetic sea water from 273.15 to $318.15 \mathrm{~K}$. The Journal of Chemical Thermodynamics 1990, 22, 113-127. [CrossRef]

46. Lee, K.; Kim, T.-W.; Byrne, R.H.; Millero, F.J.; Feely, R.A.; Liu, Y.-M. The universal ratio of boron to chlorinity for the North Pacific and North Atlantic oceans. Geochim. Cosmochim. Acta 2010, 74, 1801-1811. [CrossRef]

47. Ritchie, R.J. Consistent sets of spectrophotometric chlorophyll equations for acetone, methanol and ethanol solvents. Photosynth. Res. 2006, 89, 27-41. [CrossRef] [PubMed]

48. Stimson, J.; Kinzie, R.A. The temporal pattern and rate of release of zooxanthellae from the reef coral Pocillopora damicornis (Linnaeus) under nitrogen-enrichment and control conditions. J. Exp. Mar. Biol. Ecol. 1991, 153, 63-74. [CrossRef]

49. Courtial, L.; Roberty, S.; Shick, J.M.; Houlbrèque, F.; Ferrier-Pagès, C. Interactive effects of ultraviolet radiation and thermal stress on two reef-building corals. Limnol. Oceanogr. 2017, 62, 1000-1013. [CrossRef]

50. Roberty, S.; Fransolet, D.; Cardol, P.; Plumier, J.C.; Franck, F. Imbalance between oxygen photoreduction and antioxidant capacities in Symbiodinium cells exposed to combined heat and high light stress. Coral Reefs 2015, 34, 1063-1073. [CrossRef]

51. Spencer Davies, P. Short-term growth measurements of corals using an accurate buoyant weighing technique. Mar. Biol. 1989, 101, 389-395. [CrossRef]

52. Dang, K.V.; Pierangelini, M.; Roberty, S.; Cardol, P. Alternative Photosynthetic Electron Transfers and Bleaching Phenotypes Upon Acute Heat Stress in Symbiodinium and Breviolum spp. (Symbiodiniaceae) in Culture. Front. Mar. Sci. 2019, 6. [CrossRef]

53. Roberty, S.; Bailleul, B.; Berne, N.; Franck, F.; Cardol, P. PSI Mehler reaction is the main alternative photosynthetic electron pathway in Symbiodinium sp., symbiotic dinoflagellates of cnidarians. New Phytol. 2014, 204, 81-91. [CrossRef] [PubMed]

54. Xiang, T.; Lehnert, E.; Jinkerson, R.E.; Clowez, S.; Kim, R.G.; DeNofrio, J.C.; Pringle, J.R.; Grossman, A.R. Symbiont population control by host-symbiont metabolic interaction in Symbiodiniaceae-cnidarian associations. Nat. Commun. 2020, 11, 108. [CrossRef] [PubMed]

55. Turpin, D.H.; Elrifi, I.R.; Birch, D.G.; Weger, H.G.; Holmes, J.J. Interactions between photosynthesis, respiration, and nitrogen assimilation in microalgae. Can. J. Bot. 1988, 66, 2083-2097. [CrossRef]

56. Turpin, D.H. Effects of inorganic N availability on algal photosynthesis and carbon metabolism. J. Phycol. 1991, 27, 14-20. [CrossRef]

57. Fam, R.R.; Hiong, K.C.; Choo, C.Y.; Wong, W.P.; Chew, S.F.; Ip, Y.K. Molecular characterization of a novel algal glutamine synthetase (GS) and an algal glutamate synthase (GOGAT) from the colorful outer mantle of the giant clam, Tridacna squamosa, and the putative GS-GOGAT cycle in its symbiotic zooxanthellae. Gene 2018, 656, 40-52. [CrossRef]

58. Forde, B.G.; Lea, P.J. Glutamate in plants: Metabolism, regulation, and signalling. J. Exp. Bot. 2007, 58, 2339-2358. [CrossRef]

59. Marubini, F.; Ferrier-Pagès, C.; Furla, P.; Allemand, D. Coral calcification responds to seawater acidification: A working hypothesis towards a physiological mechanism. Coral Reefs 2008, 27, 491-499. [CrossRef] 
60. Hoegh-Guldberg, O. Population dynamics of symbiotic zooxanthellae in the coral Pocillopora damicornis exposed to elevated ammonium $\left(\mathrm{NH}_{4} \mathrm{Cl}\right)$ concentrations. Pac. Sci. 1994, 48, 263-272.

61. Muller-Parker, G.; McCloskey, L.R.; Hoegh-Guldberg, O.; McAuley, P. Effect of ammonium enrichment on animal and algal biomass of the coral Pocillopora damicornis. Pac. Sci. 1994, 48, 273-283.

62. Gordillo, F.J.; Niell, F.X.; Figueroa, F.L. Non-photosynthetic enhancement of growth by high $\mathrm{CO}_{2}$ level in the nitrophilic seaweed Ulva rigida C. Agardh (Chlorophyta). Planta 2001, 213, 64-70. [CrossRef]

63. Lachmann, S.C.; Mettler-Altmann, T.; Wacker, A.; Spijkerman, E. Nitrate or ammonium: Influences of nitrogen source on the physiology of a green alga. Ecol. Evol. 2019, 9, 1070-1082. [CrossRef] [PubMed]

64. Zou, D. Effects of elevated atmospheric $\mathrm{CO}_{2}$ on growth, photosynthesis and nitrogen metabolism in the economic brown seaweed, Hizikia fusiforme (Sargassaceae, Phaeophyta). Aquaculture 2005, 250, 726-735. [CrossRef]

65. Luo, Y.; Field, C.B.; Mooney, H.A. Predicting responses of photosynthesis and root fraction to elevated $\left[\mathrm{CO}_{2}\right] \mathrm{a}$ : Interactions among carbon, nitrogen, and growth*. Plant Cell Environ. 1994, 17, 1195-1204. [CrossRef]

66. Krueger, T.; Horwitz, N.; Bodin, J.; Giovani, M.-E.; Escrig, S.; Fine, M.; Meibom, A. Intracellular competition for nitrogen controls dinoflagellate population density in corals. Proceedings of the Royal Society B 2020, 287, 20200049. [CrossRef] [PubMed]

67. Morris, L.A.; Voolstra, C.R.; Quigley, K.M.; Bourne, D.G.; Bay, L.K. Nutrient Availability and Metabolism Affect the Stability of Coral-Symbiodiniaceae Symbioses. Trends Microbiol. 2019, 27, 678-689. [CrossRef] [PubMed]

68. Baker, D.M.; Freeman, C.J.; Wong, J.C.; Fogel, M.L.; Knowlton, N. Climate change promotes parasitism in a coral symbiosis. ISME J. 2018, 12, 921-930. [CrossRef]

69. Wooldridge, S.A. Breakdown of the coral-algae symbiosis: Towards formalising a linkage between warm-water bleaching thresholds and the growth rate of the intracellular zooxanthellae. Biogeosciences 2013, 10. [CrossRef]

70. Wiedenmann, J.; D'Angelo, C.; Smith, E.G.; Hunt, A.N.; Legiret, F.-E.; Postle, A.D.; Achterberg, E.P. Nutrient enrichment can increase the susceptibility of reef corals to bleaching. Nat. Clim. Chang. 2013, 3, 160. [CrossRef]

71. Ezzat, L.; Maguer, J.-F.; Grover, R.; Ferrier-Pagès, C. New in sights into carbon acquisition and exchanges within the coral-dinoflagellate symbiosis under $\mathrm{NH}_{4}{ }^{+}$and $\mathrm{NO}_{3}{ }^{-}$supply. Proc. R. Soc. B Biol. Sci. 2015, 282, 20150610. [CrossRef]

72. Tremblay, P.; Gori, A.; Maguer, J.F.; Hoogenboom, M.; Ferrier-Pagès, C. Heterotrophy promotes the re-establishment of photosynthate translocation in a symbiotic coral after heat stress. Sci. Rep. 2016, 6, 38112. [CrossRef]

73. Galli, G.; Solidoro, C. ATP supply may contribute to light-enhanced calcification in corals more than abiotic mechanisms. Front. Mar. Sci. 2018, 5, 68. [CrossRef]

74. Marubini, F.; Thake, B. Bicarbonate addition promotes coral growth. Limnol. Oceanogr. 1999, 44, 716-720. [CrossRef]

75. Allemand, D.; Furla, P.; Benazet-Tambutte, S. Mechanisms of carbon acquisition for endosymbiont photosynthesis in Anthozoa. Can. J. Bot. Revue Can. De Bot. 1998, 76, 925-941. [CrossRef]

76. Tanaka, Y.; Miyajima, T.; Koike, I.; Hayashibara, T.; Ogawa, H. Imbalanced coral growth between organic tissue and carbonate skeleton caused by nutrient enrichment. Limnol. Oceanogr. 2007, 52, 1139-1146. [CrossRef]

77. Le Hénaff, M.; Muller-Karger, F.E.; Kourafalou, V.H.; Otis, D.; Johnson, K.A.; McEachron, L.; Kang, H. Coral mortality event in the Flower Garden Banks of the Gulf of Mexico in July 2016: Local hypoxia due to cross-shelf transport of coastal flood waters? Cont. Shelf Res. 2019, 190, 103988. [CrossRef]

78. Bell, P.R.F.; Elmetri, I.; Lapointe, B.E. Evidence of large-scale chronic eutrophication in the Great Barrier Reef: Quantification of chlorophyll a thresholds for sustaining coral reef communities. AMBIO 2014, 43, 361-376. [CrossRef]

(C) 2020 by the authors. Licensee MDPI, Basel, Switzerland. This article is an open access article distributed under the terms and conditions of the Creative Commons Attribution (CC BY) license (http://creativecommons.org/licenses/by/4.0/). 